\title{
Betulinic acid and the pharmacological effects of tumor suppression (Review)
}

\author{
XIA ZHANG ${ }^{*}$, JINGYU HU* and YAN CHEN \\ Department of Hematology, Union Hospital, Tongji Medical College, Huazhong University of Science and Technology, \\ Wuhan, Hubei 430022, P.R. China
}

Received September 12, 2015; Accepted September 21, 2016

DOI: $10.3892 / \mathrm{mmr} .2016 .5792$

\begin{abstract}
Betulinic acid (BA), a lupane-type pentacyclic triterpenoid saponin from tree bark, has the potential to induce the apoptosis of cancer cells without toxicity towards normal cells in vitro and in vivo. The antitumor pharmacological effects of BA consist of triggering apoptosis via the mitochondrial pathway, regulating the cell cycle and the angiogenic pathway via factors, including specificity protein transcription factors, cyclin D1 and epidermal growth factor receptor, inhibiting the signal transducer and activator of transcription 3 and nuclear factor- $\kappa \mathrm{B}$ signaling pathways, preventing the invasion and metastasis of tumor cells, and affecting the expression of topoisomerase I, p53 and lamin B1. In previous years, several studies have shown its antitumor effect, initially applied to malignant melanoma, however, it also has broad efficacies against most solid types of tumor from different regions of the body. There have been few investigations in hematological malignancies, however, this direction may offer potential in such a novel field of research. In this review, the primary pharmacological effects of BA in tumors, particularly in hematological malignancies are discussed.
\end{abstract}

\section{Contents}

1. Introduction

2. Sources of BA

3. Antitumor effects of BA in solid tumor types

4. Antitumor effects of BA in hematological malignancies

5. Outlook

Correspondence to: Professor Yan Chen, Department of Hematology, Union Hospital, Tongji Medical College, Huazhong University of Science and Technology, 1277 Jiefang Avenue, Wuhan, Hubei 430022, P.R. China

E-mail: yanchen981@163.com

${ }^{*}$ Contributed equally

Key words: betulinic acid, antitumor pharmacological effects, solid tumor, hematological malignancies, mitochondrial pathway, cell cycle

\section{Introduction}

Betulinic acid (BA) is a lupane-type pentacyclic triterpenoid saponin (3ß-hydroxy-lup-20 (29)-en-28-oic acid; MW, 456.71; Fig. 1), which exists in the bark of a variety of natural plants, principally in Betula. It has been investigated extensively in previous decades due to its beneficial properties, including anticancer, anti-inflammatory, anti-angiogenic, and immunomodulatory effects, its anthelmintic activity and its anti-human immunodeficiency virus effects. Its antitumor effects are higher at a reduced $\mathrm{pH}(<6.8)$, a characteristic of several types of tumor (1-3).

In previous decades, BA has been shown to have a marked antitumor therapeutic effect in melanoma cells and several types of solid tumor, including glioblastoma (4), lung carcinoma (5), breast carcinoma (6), colorectal carcinoma (7) and prostate carcinoma (8). In addition, the antitumor effects on hematological malignancies have been investigated in our previous studies and in those of others in previous years $(1,9-11)$.

The reported primary mechanisms of the anticancer effects of BA treatment are shown in Fig. 2 and described below.

Promotion of apoptosis by activation of the mitochondrial pathway. BA improves the level of reactive oxygen species (ROS) production and alters the mitochondrial membrane potential gradient, followed by the release of cytochrome $c$ (Cyt $c$ ), which causes the mitochondrial-mediated apoptosis of tumor cells via a caspase-dependent mechanism and apoptosis inducing factor $(1,12,13)$. It has been demonstrated that there is a link between ROS and the p38 and stress-activated protein (SAP) kinase/c-Jun N-terminal kinase (JNK) in melanoma cells. This indicates that ROS act upstream of the mitogen-activated protein kinases (MAPKs) in the signaling pathway of BA (14). In addition, autophagy has been shown to occur downstream of the mitochondrial damage induced by BA (15).

Regulation of cell cycle and the angiogenic pathway via specificity protein ( $S p$ ) transcription factors, cyclin DI and epidermal growth factor receptor (EGFR). BA can inhibit cancer cell growth and proliferation via cell cycle arrest. Drugs, including BA, can inhibit the protein expression of Sp1, $\mathrm{Sp} 2$ and Sp4 through the microRNA (miR)-27a-ZBTB10-Sp1 axis and slow down the aggressiveness of the tumor (16-19). 
Inhibition of the signal transducer and activator of transcription 3 (STAT3) and nuclear factor $(\mathrm{NF})-\kappa B$ signaling pathways. BA can downregulate the activation of STAT3 through the upregulation of Src homology 2 domain-containing phosphatase 1 (SHP-1), and affect the STAT3/HIF-1/VEGF signal pathway (20-22). The expression of $N F-\kappa B$ can be inhibited by reducing the activation of inhibitor of $N F-\kappa B(I \kappa B \alpha)$ kinase $(\mathrm{IKK} \beta)$ and phosphorylation of I $\mathrm{B} \mathrm{B} \alpha$ with BA (23).

Prevention of the invasion and metastasis. The invasion and metastasis of malignancies is prevented via epithelial-mesenchymal transition (EMT) and inhibition of topoisomerase I (24).

The aim of this review was to discuss the primary pharmacological effects of BA in solid types of tumor and in hematological malignancies, and to provide a valuable reference for future investigations in the hematological system.

\section{Sources of BA}

BA is a type of pentacyclic triterpene acid, which is found in the bark of several species of plant. As a natural compound, it has a wide range of biological activities, and also the characteristics of low toxicity and a high safety index. BA has attracted increasing attention over previous years due to these properties (25).

Previous studies have revealed three sources of BA. Its direct extraction from plants is the earliest and most direct source. The primary raw material used for BA extraction is Betula bark. The bark of Platanus acerifolia, Vochysia divergen, Euphorbiacea, Ficus pandurata Hance, and the leaves of Vitex negundo and Pterospermum heterophyllum Hance can also be used as raw material to extract BA. However, the extraction rate (up to $3.3 \%$ ) is low due to the low content of BA in the bark of these plants. In order to increase the extraction efficiency, the preparation of semisynthetic BA has been introduced. This method provides a higher rate of extraction from betulin, which is an associated natural compound and important constituent of birch bark (22-30\%), which can be converted into BA in high yields through an oxidation process $(26,27)$. Another method used to extract BA is microbial fermentation. Microbial transformation has several advantages, including mild reaction conditions, low cost and reduced pollution. Several types of microbes have been used, namely Aspergillus oryzae AS 3.49, Aspergillus sp. WZ, Aspergillus foetidus ZU-G1 and Trichoderma koningii ZJ. However, further investigations are required for the large-scale preparation of BA with the use of microbes (28).

\section{Antitumor effects of BA in solid tumor types}

BA was initially confirmed as a selective inhibitor of human melanoma cells (29). BA has attracted attention due to its unique anticancer activities of selective tumor growth inhibition or apoptosis, without damaging normal cells, at a concentration $>100 \mathrm{mg} / \mathrm{kg}$ body weight (30). Several types of solid cancer cell have been shown to be sensitive towards BA. The following section focuses on the mechanisms underlying the effects of BA in solid tumor treatment.
Malignant melanoma. Malignant melanoma, to which individuals of European origin are vulnerable, accounted for $1.6 \%$ of new cancer cases in 2012 worldwide (31). As a consequence, it is imperative to identify an effective treatment approach. BA is a specific toxic reagent towards melanoma cells and was first used for the treatment of melanoma. Tan et al (14) demonstrated that treatment of UISO-Mel-1 human melanoma cells with BA leads to the activation, via phosphorylation, of pro-apoptotic MAPK proteins, P38 and SAP/JNK, the formation of ROS and the upregulation of caspase (14). Pisha et al (29) initially reported that BA induced the apoptosis of a number of melanoma cell lines, including MEL-1, 2, 3 and 4, with half maximal effective dose values ranging between 0.5 and $4.8 \mu \mathrm{g} / \mathrm{ml}$. In addition, BA interferes with EMT-associated changes, a mechanism to antagonize invasive melanoma cells A375 at a concentration of $10 \mu \mathrm{M}$, whereas $\mathrm{BA}$ reduces $\mathrm{A} 375$ cell proliferation at a concentration of $50 \mu \mathrm{M}$ (32).

Cervical cancer. BA activates the endoplasmic reticulum pathway and the ROS-mediated mitochondrial pathway to induce apoptosis of HeLa cells. Potze et al (33) demonstrated that BA causes cell membrane rupture, apoptosis and mitochondrial depolarization in HeLa cell lines, with an minimum effective concentration of $7.5 \mu \mathrm{g} / \mathrm{ml}$, reaching a plateau at $10 \mu \mathrm{g} / \mathrm{ml}$

BA increases the levels of microtubule-associated protein 1 light chain 3 (LC3-II) more markedly in HeLa cell lines, compared with DMSO-treated control groups, and the BA-treated HeLa cell lines have a potent inducing effect on the expression of p62. BA can also inhibit the autophagic flux by increasing the degradation of long-lived proteins following $14 \mathrm{~h}$ medium replacement (33).

The B cell lymphoma-2 (Bcl-2) family members interact with each other to maintain mitochondrial integrity and regulate cell apoptosis. The two predominant types of $\mathrm{Bcl}-2$ proteins include anti-apoptotic proteins, including Bcl-2-A1, Bcl-2, Bcl-extra large (Bcl-xL), Bcl-2-like protein 2, and myeloid cell leukemia-1, and pro-apoptotic proteins, including Bcl-2-associated death promoter, Bcl-2 homologous antagonist/killer, Bcl-2-associated $\mathrm{X}$ protein (Bax), $\mathrm{BH} 3$-interacting domain death agonist, Bcl-2-interacting killer, Bcl-2-interacting mediator of cell death, activator of apoptosis harakiri, phorbol-12-myristate-13-acetate-induced protein 1 and p53-upregulated modulator of apoptosis. BA downregulates Bcl-2 and upregulates the Bax gene in HeLa cell lines (34-36).

Breast cancer. Previous research demonstrated that $\mathrm{Sp}$ is overexpressed in tumors (19). Previous reports have shown that BA mediates antitumor activity by downregulating the Sp1 transcription factor. Knocking down the expression of Sp1 inhibits tumor growth and angiogenesis in xenograft models $(10,19)$. ZBTB10 is a transcriptional repressor of Sp transcription factors, and drugs inhibit Sp transcription factors through the microRNA (miR)-27a-ZBTB10-Sp1 axis. BA induces the apoptosis of MDA-MB-231 estrogen-receptor-negative breast cancer cell lines by downregulating the mRNA and protein levels of Sp1, Sp3 and Sp4 at concentrations of 2.5-10 $\mu \mathrm{M}$, decreasing the expression of miR-27a and increasing the levels of ZBTB10 in vitro and in vivo $(16,37,38)$. 


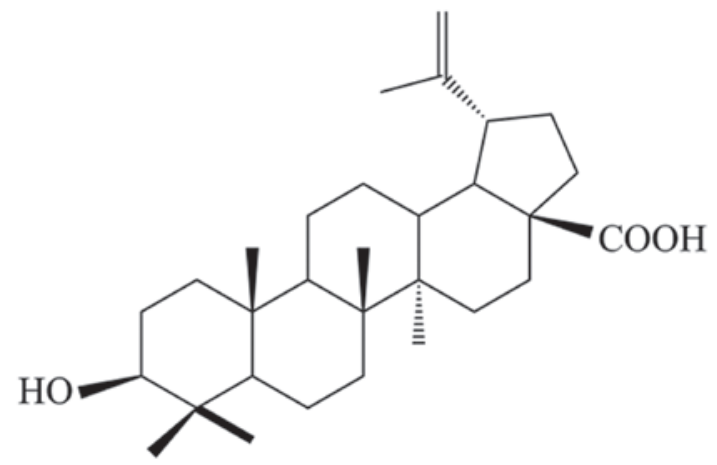

Figure 1. Chemical structure of betulinic acid $\left(\mathrm{C}_{30} \mathrm{H}_{48} \mathrm{O}_{3}\right.$; $\left.\mathrm{MW}, 456.71\right)$.

Yin Yang 1 (YY1), an Sp-regulated gene, is a key upstream regulator of ErbB2. BA inhibits the expression of YY1 in BT474 and MDA-MB-453 cell lines. The activation of cannabinoid type 1 (CB1) and $\mathrm{CB} 2$ receptors, which modulate the miR-27a-ZBTB10-Sp1 axis, mediate the effects of Sp transcription factors and ErbB2 on these two cell lines (39).

P53, a well-known tumor suppressor, mediates cell cycle arrest and apoptosis (40). BA induces the apoptosis of MCF-7 and T47D breast cancer cell lines in an p53-independent apoptotic pathway with half maximal inhibitory concentration $\left(\mathrm{IC}_{50}\right)$ values of 12.3 and $9.8 \mu \mathrm{g} / \mathrm{ml}$, respectively, following $72 \mathrm{~h}$ incubation $(6,41)$.

Lung carcinoma, colorectal carcinoma and gastric adenocarcinoma. Lung cancer and colorectal cancer are considered to be major contributors to incidence and mortality rates $(42,33)$. In a previous study in nude mice, compared with control mice, BA-treated transplanted tumors of A549 lung cancer or SW480 colon cancer cell lines grew at a slower rate, with an $\mathrm{IC}_{50}$ of $4.3 \mu \mathrm{g} / \mathrm{ml}$ in the A549 cell lines, determined using MTT (44).

BA inhibits the proliferation of colon cancer cells and xenograft tumor growth. It induces the proteasome-dependent and -independent downregulation of $\mathrm{Sp}$ transcription factors, including Sp1, Sp3 and Sp4, in SW480 and RKO cell lines, at concentrations of 5-10 $\mu \mathrm{M}$. In addition, BA disrupts the expression of miR-27a and ZBTB10 mRNA in RKO cell lines $(45,46)$. The expression levels of Sp-regulated genes, including cyclin D1, p65, EGFR and Bcl-2 also decrease. In addition, BA can markedly decrease the percentage of RKO cells in the G0/G1 and S phases, and increase the percentage in the $\mathrm{G} 2 / \mathrm{M}$ phase $(47,48)$.

BA mediates $\mathrm{G} 2 / \mathrm{M}$ cell cycle arrest and downregulates the protein expression of Hiwi and cyclin B1 in the AGS human gastric adenocarcinoma cell line, with an $\mathrm{IC}_{50}$ of $12.99 \mu \mathrm{g} / \mathrm{ml}(49)$.

Vascular endothelial cell growth factor (VEGF) is a regulator of physiological and pathological angiogenesis. It is expressed at high levels in several types of solid tumor, including colon carcinoma and breast cancer. BA can decrease the expression of VEGF via Sp proteins, thus having an antiangiogenic role $(50,51)$.

Pancreatic cancer and hepatocellular carcinoma. The lamin B1 protein, an important member of the lamin protein family (52), regulates apoptosis, proliferation, invasion and metastasis (53). The expression of lamin B1 is reduced in lung cancer, colon cancer, breast cancer, bronchial carcinoma and gastric cancer $(54,55)$, whereas the expression of lamin B1 is increased in prostate cancer and hepatocellular carcinoma $(56,57)$.

The expression of lamin B1 is positively correlated with the growth of cancer. Sp1, a lamin B1 downstream gene, may regulate the expression of lamin B1. However, BA suppresses the expression of lamin B1 in pancreatic cancer cells independent of the Sp1 protein in vitro and in xenograft models (58-60).

The upregulation of lamin B1 in hepatocellular carcinoma tumors correlates with tumor size, stage and nodule number. Elevated levels of plasma lamin B1 can predict early stage hepatocellular carcinoma with a sensitivity of $76 \%$ and a specificity of $82 \%$ (61).

Prostate cancer, bladder cancer and endometrial adenocarcinoma. The dysregulation of STAT3 is involved in tumor cell survival, proliferation, apoptosis and metastasis. BA mediates anticancer activity through inhibiting STAT3 in solid tumors. It was reported that BA may be a potent anti-angiogenic drug in prostate cancer, affecting the expression and transcription of hypoxia-indicible factor (HIF)-1 $\alpha$, STAT3 and VEGF, and capillary tube formation $(20,22)$.

In endometrial adenocarcinoma cells, BA is vital in cancer development and progression. It inhibits prolidase, which catalyzes collagen degradation in the final step, and decreases the expression of $\alpha 1$ and $\alpha 2$ integrin, HIF-1, VEGF, glucose transporter-1, erythropoietin-1, carbonic anhydrase and glyceraldehyde-3-phosphate dehydrogenase $(62,63)$.

$\mathrm{NF}-\kappa \mathrm{B}$, a key regulator of stress-induced transcriptional activation, regulates cell survival, proliferation, apoptosis, immune responses and adaptive responses to alterations in cellular redox balance $(23,64)$. BA inhibits the expression of $\mathrm{NF}-\kappa \mathrm{B}$, which leads to a decrease in the activity of IKK $\beta$ and phosphorylation of I $\mathrm{Ba}$ in $\mathrm{PC}-3$ human prostate carcinoma cells. BA treatment for $24 \mathrm{~h}$ results in a dose-dependent reduction in cell viability, which ranges between 2.9 and $91.2 \%$ in PC-3 cells at concentrations of $1-40 \mu \mathrm{M}$. Furthermore, the protein expession of cyclin D1 is lowered in a mouse model of prostate cancer treated with BA (10 mg/kg) (8).

The expression of EGFR is correlated with vascularity. BA can significantly downregulate the expression of the Sp-dependent gene, EGFR, through repression of the Sp1, Sp3 and Sp4 proteins in 253JB-V and KU7 bladder cancer cells at a concentration of 5 or $10 \mu \mathrm{M}(19,65)$.

Head and neck carcinoma. The RET proto-oncogene, involved in recurrent chromosomal rearrangements, is found in thyroid and lung cancer. Of all papillary thyroid carcinoma (PTC) cases, $\sim 20 \%$ are attributed to $\mathrm{RET} / \mathrm{PTC}$ rearrangements $(66,67)$.

Topoisomerases, a class of ubiquitous enzymes located in the cell nucleus, catalyze the fracture and combination of DNA strands. BA secludes to topoisomerase I in the nucleoplasm. Therefore, BA inhibits topoisomerase I DNA cleavage complex formation. Coincidentally, fragile site breakage of the RET proto-oncogene is affected by DNA topoisomerase I (68-70).

The BA derivative, compound 15, shows marked inhibition of SW1736 anaplastic thyroid cancer cell lines in a short 


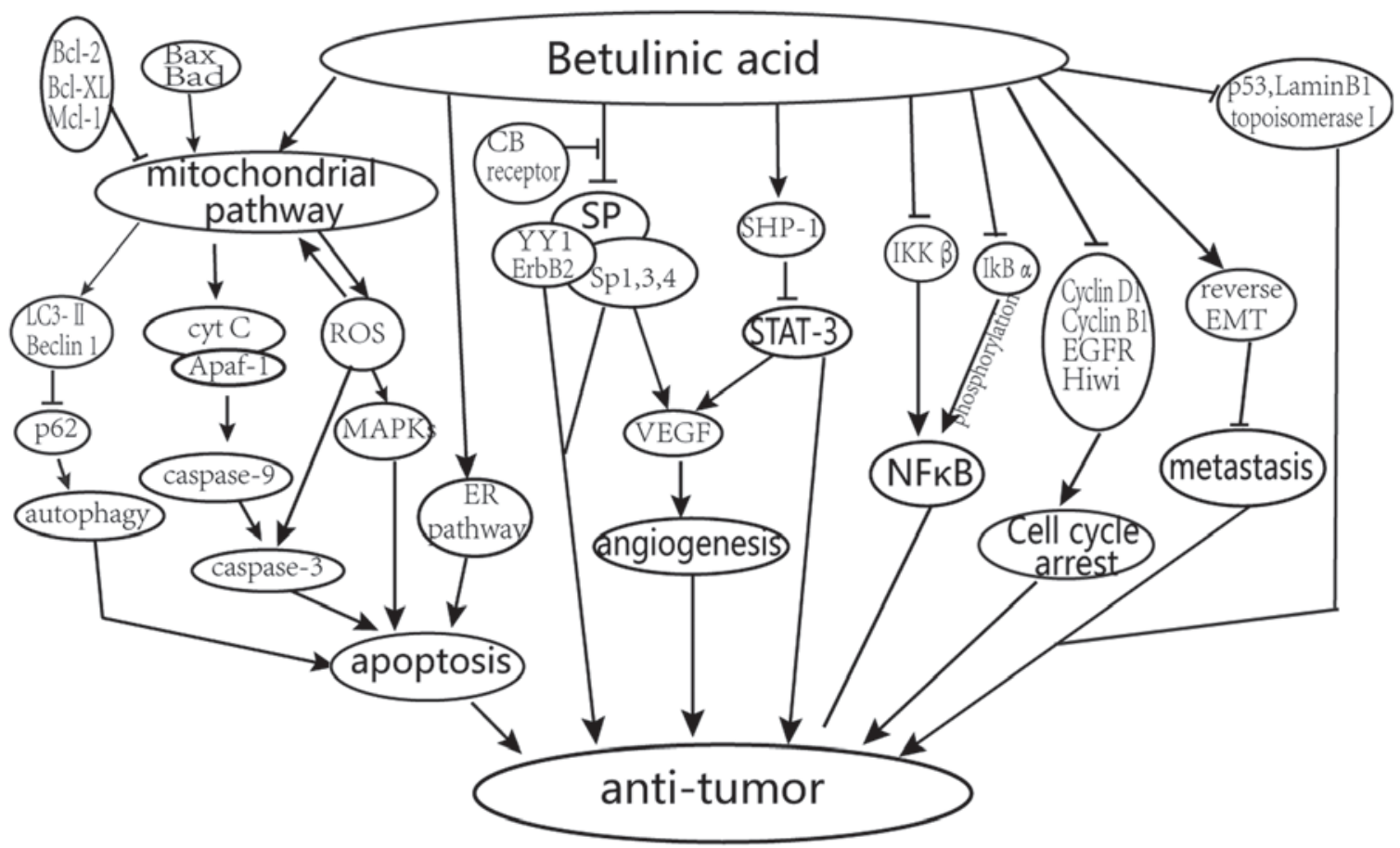

Figure 2. Diagram showing the antitumor pharmacological effects of betulinic acid.

duration with an $\mathrm{IC}_{50}$ of $3.54 \pm 0.66 \mu \mathrm{M}$ (71). Compared with BA, B10, a semi-synthetic glycosylated derivative of BA, shows a higher cytotoxicity in glioma cell lines. B10 induces cell death by inducing autophagy and lysosomal permeabilization in glioblastoma cells. It induces autophagy and abrogates the autophagic flux on a panel of glioblastoma cell lines. The release of lysosomal enzymes contributes to B10-triggered cell death. B10 decreases the level of poly ADP ribose polymerase, the apoptotic protein, and survivin (72).

The phosphoinositide 3-kinase (PI3K)/Akt/mammalian target of rapamycin (mTOR) pathway, integrating extra- and intracellular survival signals, stimulates cell growth and inhibits cell death $(73,74)$. In addition, the PI3K/Akt signal can regulate the activity and stability of lysosomes (75). The $\mathrm{PI} 3 \mathrm{~K} / \mathrm{Akt} / \mathrm{mTOR}$ signaling pathway is inhibited in B10-treated $(18 \mu \mathrm{M}) \mathrm{U} 87 \mathrm{MG}$ cells by decreasing the phosphorylation of Akt, a downstream target of PI3K, which is an upstream target of mTOR. The activation of caspase-3, lysosomal permeabilization and cell death are decreased significantly when ATG7, ATG5 or BECN1 are downregulated by RNA interference (76).

\section{Antitumor effects of BA in hematological malignancies}

Currently, the therapeutical effect of BA against hematological malignancies predominantly focuses on multiple myeloma, acute leukemia and lymphoma. This review elaborates on the correlative functional mechanism of BA-treated cell lines.

Multiple myeloma. The U266 and MM.1S human multiple myeloma cell lines have been investigated in order to determine whether BA can modulate the STAT3 pathway. BA downregulates the activation of STAT3 (22) through the upregulation of SHP-1 (77). Thus, BA inhibits the activation of STAT3, Src kinase, janus kinase (JAK)1 and JAK2 (77). The ability of BA to inhibit STAT3 activation is abolished and BA-induced cell death is rescued when the SHP-1 gene is silenced. In multiple myeloma, the expression levels of STAT3-regulated gene products, including Bcl-extra large (Bcl-xL), Bcl-2, cyclin D1 and survivin, are downregulated by BA (77).

In our previous study, it was demonstrated that BA inhibits cell proliferation and autophagic flux, and induces apoptosis in a time-dose-dependent manner in KM3 multiple myeloma cells, which was bound up with the activation of caspase 3 . These experimental results indicated that the proliferation of the KM3 cells was suppressed when the cells were treated with BA $(5-25 \mu \mathrm{g} / \mathrm{ml})$. The $\mathrm{IC}_{50}$ values at 12,24 and $36 \mathrm{~h}$ were $22.29,17.36$ and $13.06 \mu \mathrm{g} / \mathrm{ml}$, respectively. However, the cells were sensitized to BA-induced apoptosis when they were treated with Z-DEVD-FMK, a specific inhibitor of caspase 3. The accumulation of LC3-II and P62 in KM3 cells treated with dose-dependent BA increased, which indicated the suppression of autophagic flux. Furthermore, the expression of Beclin 1, an important inducer of autophagy, was downregulated in the KM3 cells treated with BA (78). Our previous study also confirmed that BA can induce the apoptosis of RPMI-8226 multiple myeloid cell lines via modulating the apoptosis-associated genes, Bcl-xL and caspase 3 (79). This efficiency showed a time- and dose-dependency. In the RPMI-8226 cell lines, BA also affected the cell cycle in the G1/S phase and arrested cells in the G0/G1 phase. The $\mathrm{IC}_{50}$ values of BA to RPMI-8226 cells at 24 and $48 \mathrm{~h}$ were $10.156 \pm 0.659$ and $5.434 \pm 0.212 \mu \mathrm{g} / \mathrm{ml}$, respectively (79).

Acute leukemia. Ehrhardt et al (80) found that BA induced marked apoptosis in $65 \%$ of primary pediatric acute leukemia cells and in all leukemia cell lines assessed through the mechanism of induction of $\mathrm{Cy} c$ and second mitochondria-derived activator of caspases. In all cell lines assessed, including the 
SKW6, HUT 78 and CEM T-cell leukemia cell lines, the BJAB, NALM6 and BOE B-cell lines and the HL-60 myeloid cell line, the cells showed sensitivity towards BA-induced apoptosis at a concentration of $10 \mu \mathrm{g} / \mathrm{ml}$ (80). Kumar et al (81) found that the methanolic extract of Dillenia indica L. fruits showed significant antileukemic activity in U937, HL60 and K562 human leukemic cell lines. BA can induce the apoptosis of these leukemic cell lines with $\mathrm{IC}_{50}$ values of $13.73 \pm 0.89,12.84 \pm 1.23$ and $15.27 \pm 1.16 \mu \mathrm{g} / \mathrm{ml}$, respectively (81). Our previous study also showed that BA inhibited the proliferation of K562 cells through the induction of cell cycle arrest, and upregulation of the protein expression levels of Bcl-2-associated X protein and caspase 3 . BA was cytotoxic towards K562 cells with an $\mathrm{IC}_{50}$ of $21.26 \mu \mathrm{g} / \mathrm{ml}$ at $24 \mathrm{~h}(82)$. It was also found that BA is important in T lymphocytic leukemia. BA is able to inhibit the proliferation of Jurkat cells by regulating the cell cycle, with arrest of cells at the G0/G1 phase and the induction of apoptosis. The antitumor effects of BA were associated with the downregulated expression levels of cyclin D3 and Bcl-xL. The proliferation of Jurkat cells was decreased in the BA-treated group with an $\mathrm{IC}_{50}$ value of $70 \mu \mathrm{mol} / 1$ at $24 \mathrm{~h}(83)$.

Lymphoma. Our previous study in the Raji Burkitt lymphoma cell line showed that BA can induce cell cycle arrest and apoptosis via suppressing the expression of the D-type cyclin, cyclin D3. The $\mathrm{IC}_{50}$ values of BA at 24,48 and $72 \mathrm{~h}$ were $39.44 \pm 0.65,26.26 \pm 2.39$ and $15.35 \pm 1.83 \mu \mathrm{g} / \mathrm{ml}$, respectively. BA primarily caused the arrest of Raji lymphoma cell lines in the G0/G1 phase at $24 \mathrm{~h}(84)$.

\section{Outlook}

In conclusion, BA is a promising antitumor reagent. It mediates selective cell death without cytotoxicity towards normal cells and tissues. The antitumor activities described above indicate BA as a veritable candidate for clinical cancer treatment. In addition, previous studies have demonstrated that BA is involved in the treatment of solid tumors, however, there are few reports on BA-treated hematological malignancies, the elucidation of which may be of potential value in such a novel field of research, and indicates a direction for future investigations.

\section{Acknowledgements}

This study was supported by the grants from the National Natural Science Foundation of China (grant nos. 81372541 and 81070429).

\section{References}

1. Gheorgheosu D, Duicu O, Dehelean C, Soica C and Muntean D: Betulinic acid as a potent and complex antitumor phytochemical: A minireview. Anticancer Agents Med Chem 14: 936-945, 2014.

2. Dehelean CA, Soica C, Ledeti I, Aluas M, Zupko I, G Luşcan A, Cinta-Pinzaru S and Munteanu M: Study of the betulin enriched birch bark extracts effects on human carcinoma cells and ear inflammation. Chem Cent J 6: 137, 2012.

3. Csuk R: Betulinic acid and its derivatives: A patent review (2008-2013). Expert Opin Ther Pat 24: 913-923, 2014.

4. Jeremias I, Steiner $\mathrm{HH}$, Benner A, Debatin KM and Herold-Mende C: Cell death induction by betulinic acid, ceramide and TRAIL in primary glioblastoma multiforme cells. Acta Neurochir (Wien) 146: 721-729, 2004.
5. Hsu TI, Wang MC, Chen SY, Huang ST, Yeh YM, Su WC, Chang WC and Hung JJ: Betulinic acid decreases specificity protein $1(\mathrm{Spl})$ level via increasing the sumoylation of $\mathrm{spl}$ to inhibit lung cancer growth. Mol Pharmacol 82: 1115-1128, 2012.

6. Tiwari R, Puthli A, Balakrishnan S, Sapra BK and Mishra KP: Betulinic acid-induced cytotoxicity in human breast tumor cell lines MCF-7 and T47D and its modification by tocopherol. Cancer Inves 32: 402-408, 2014.

7. Jung GR, Kim KJ, Choi CH, Lee TB, Han SI, Han HK and Lim SC: Effect of betulinic acid on anticancer drug-resistant colon cancer cells. Basic Clin Pharmacol Toxicol 101: 277-285, 2007.

8. Rabi T, Shukla S and Gupta S: Betulinic acid suppresses constitutive and TNFalpha-induced NF-kappaB activation and induces apoptosis in human prostate carcinoma PC-3 cells. Mole Carcinog 47: 964-973, 2008.

9. Gao Y, Jia Z, Kong X, Li Q, Chang DZ, Wei D, Le X, Suyun H, Huang S, Wang L, et al: Combining betulinic acid and mithramycin a effectively suppresses pancreatic cancer by inhibiting proliferation, invasion and angiogenesis. Cancer Res 71: 5182-5193, 2011.

10. Soica C, Danciu C, Savoiu-Balint G, Borcan F, Ambrus R, Zupko I, Bojin F, Coricovac D, Ciurlea S, Avram S, et al: Betulinic acid in complex with a gamma-cyclodextrin derivative decreases proliferation and in vivo tumor development of non-metastatic and metastatic B164A5 cells. Int J Mol Sci 15: 8235-8255, 2014.

11. Mullauer FB, Kessler JH and Medema JP: Betulinic acid, a natural compound with potent anticancer effects. Anticancer Drugs 21: 215-227, 2010.

12. Mullauer FB, Kessler JH and Medema JP: Betulinic acid induces cytochrome $c$ release and apoptosis in a Bax/Bak-independent, permeability transition pore dependent fashion. Apoptosis 14: 191-202, 2009.

13. Gibellini L, Pinti M, Nasi M, De Biasi S, Roat E, Bertoncelli L and Cossarizza A: Interfering with ROS metabolism in cancer cells: The potential role of quercetin. Cancers 2: 1288-1311, 2010.

14. Tan Y, Yu R and Pezzuto JM: Betulinic acid-induced programmed cell death in human melanoma cells involves mitogen-activated protein kinase activation. Clin Cancer Res 9: 2866-2875, 2003.

15. Mizushima N: Methods for monitoring autophagy using GFP-LC3 transgenic mice. Methods Enzymol 452: 13-23, 2009.

16. Pathi SS, Jutooru I, Chadalapaka G, Sreevalsan S, Anand S, Thatcher GR and Safe S: GT-094, a NO-NSAID, inhibits colon cancer cell growth by activation of a reactive oxygen species-microRNA-27a: ZBTB10-specificity protein pathway. Mol Cancer Res 9: 195-202, 2011.

17. Safe SH, Prather PL, Brents LK, Chadalapaka G and Jutooru I: Unifying mechanisms of action of the anticancer activities of triterpenoids and synthetic analogs. Anticancer Agents Med Chem 12: 1211-1220, 2012.

18. Papineni S, Chintharlapalli S, Abdelrahim M, Lee SO Burghardt R, Abudayyeh A, Baker C, Herrera L and Safe S: Tolfenamic acid inhibits esophageal cancer through repression of specificity proteins and c-Met. Carcinogenesis 30: 1193-1201, 2009.

19. Chadalapaka G, Jutooru I, Burghardt R and Safe S: Drugs that target specificity proteins downregulate epidermal growth factor receptor in bladder cancer cells. Mol Cancer Res 8: 739-750, 2010.

20. Yu Y, Zhao Q, Wang Z and Liu XY: Activated STAT3 correlates with prognosis of non-small cell lung cancer and indicates new anticancer strategies. Cancer Chemother Pharmacol 75: 917-922, 2015.

21. Yadav VR, Prasad S, Sung B, Kannappan R and Aggarwal BB: Targeting inflammatory pathways by triterpenoids for prevention and treatment of cancer. Toxins (Basel) 2: 2428-2466, 2010.

22. Shin J, Lee HJ, Jung DB, Jung JH, Lee HJ, Lee EO, Lee SG, Shim BS, Choi SH, Ko SG et al: Suppression of STAT3 and HIF-1 alpha mediates anti-angiogenic activity of betulinic acid in hypoxic PC-3 prostate cancer cells. PLoS One 6: e21492, 2011.

23. Wan Y, Wu YL, Lian LH, Xie WX, Li X, Ouyang BQ, Bai T, Li Q, Yang N and Nan JX: The anti-fibrotic effect of betulinic acid is mediated through the inhibition of NF-kappaB nuclear protein translocation. Chem Biol Interact 195: 215-223, 2012.

24. Chowdhury AR, Mandal S, Mittra B, Sharma S, Mukhopadhyay S and Majumder HK: Betulinic acid, a potent inhibitor of eukaryotic topoisomerase I: Identification of the inhibitory step, the major functional group responsible and development of more potent derivatives. Med Sci Monit 8: BR254-BR265, 2002. 
25. Alakurtti S, Makela T, Koskimies S and Yli-Kauhaluoma J: Pharmacological properties of the ubiquitous natural product betulin. Eur J Pharm Sci 29: 1-13, 2006.

26. Bruckner V, Kovacs J and Koczka I: Occurrence of betulinic acid in the bark of the plane tree. J Chem Soc 1: 948-951, 1948.

27. Yogeeswari P and Sriram D: Betulinic acid and its derivatives: A review on their biological properties. Curr Med Chem 12: 657-666, 2005

28. Chen QH, Liu J, Zhang HF, He GQ and Fu ML: The betulinic acid production from betulin through biotransformation by fungi. Enzyme Microb Tech 45: 175-180, 2009.

29. Pisha E, Chai H, Lee IS, Chagwedera TE, Farnsworth NR, Cordell GA, Beecher CW, Fong HH, Kinghorn AD, Brown DM, et al: Discovery of betulinic acid as a selective inhibitor of human melanoma that functions by induction of apoptosis. Nat Med 1: 1046-1051, 1995.

30. Zuco V, Supino R, Righetti SC, Cleris L, Marchesi E, Gambacorti-Passerini C and Formelli F: Selective cytotoxicity of betulinic acid on tumor cell lines, but not on normal cells Cancer Lett 175: 17-25, 2002

31. Ferlay J, Soerjomataram I, Dikshit R, Eser S, Mathers C, Rebelo M, Parkin DM, Forman D and Bray F: Cancer incidence and mortality worldwide: Sources, methods and major patterns in globocan 2012. Int J Cancer 136: E359-E386, 2015.

32. Gheorgheosu D, Jung M, Ören B, Schmid T, Dehelean C, Muntean D and Brüne B: Betulinic acid suppresses NGAL-induced epithelial-to-mesenchymal transition in melanoma. Biol Chem 394: 773-781, 2013.

33. Potze L, Mullauer FB, Colak S, Kessler JH and Medema JP: Betulinic acid-induced mitochondria-dependent cell death is counterbalanced by an autophagic salvage response. Cell Death Dis 5: e1169, 2014.

34. Williams MM and Cook RS: Bcl-2 family proteins in breast development and cancer: Could Mcl-1 targeting overcome therapeutic resistance? Oncotarget 6: 3519-3530, 2015.

35. Cheng EH, Wei MC, Weiler S, Flavell RA, Mak TW, Lindsten T and Korsmeyer SJ: BCL-2, BCL-X (L) sequester BH3 domain-only molecules preventing BAX- and BAK-mediated mitochondrial apoptosis. Mol Cell 8: 705-711, 2011.

36. Willis SN, Chen L, Dewson G, Wei A, Naik E, Fletcher JI Adams JM and Huang DC: Proapoptotic Bak is sequestered by Mcl-1 and Bcl-xL, but not Bcl-2, until displaced by BH3-only proteins. Genes Dev 19: 1294-1305, 2005.

37. Li W, Liu M, Xu YF, Feng Y, Che JP, Wang GC and Zheng JH: Combination of quercetin and hyperoside has anticancer effects on renal cancer cells through inhibition of oncogenic microRNA-27a. Oncol Rep 31: 117-124, 2014.

38. Mertens-Talcott SU, Noratto GD, Li X, Angel-Morales G, Bertoldi MC and Safe S: Betulinic acid decreases ER-negative breast cancer cell growth in vitro and in vivo: Role of Sp transcription factors and microRNA-27a: ZBTB10. Mol Carcinog 52: 591-602, 2013

39. Liu X, Jutooru I, Lei P, Kim K, Lee SO, Brents LK, Prather PL and Safe S: Betulinic acid targets YY1 and ErbB2 through cannabinoid receptor-dependent disruption of microRNA-27a: ZBTB10 in breast cancer. Mol Cancer Ther 11: 1421-1431, 2012.

40. Levine AJ: p53, the cellular gatekeeper for growth and division. Cell 88: 323-331, 1997.

41. Shi M, Liu D, Shen B and Guo N: Helpers of the cellular gatekeeper-miRNAs dance in P53 network. Biochim Biophys Acta 1805: 218-225, 2010

42. Siegel RL, Miller KD and Jemal A: Cancer Statistics, 2015 CA. Cancer J Clin 65: 5-29, 2015

43. GBD 2013 Mortality and Causes of Death Collaborators: Global, regional and national age-sex specific all-cause and cause-specific mortality for 240 causes of death, 1990-2013: A systematic analysis for the global burden of disease study 2013 Lancet 385: 117-171, 2015.

44. Mullauer FB, van Bloois L, Daalhuisen JB, Ten Brink MS, Storm G, Medema JP, Schiffelers RM and Kessler JH: Betulinic acid delivered in liposomes reduces growth of human lung and colon cancers in mice without causing systemic toxicity. Anticancer Drugs 22: 223-233, 2011

45. Chintharlapalli S, Papineni S, Lei P, Pathi S and Safe S: Betulinic acid inhibits colon cancer cell and tumor growth and induces proteasome-dependent and-independent downregulation of specificity proteins $(\mathrm{Sp})$ transcription factors. BMC Cancer 11: 371,2011 .
46. Lai Y,Zhang X,Zhang Z, Shu Y, Luo X, Yang Y, Wang X, Yang G, Li L and Feng Y: The microRNA-27a:ZBTB10-specificity protein pathway is involved in follicle stimulating hormone-induced VEGF, Cox 2 and survivin expression in ovarian epithelial cancer cells. Int J Oncol 42: 776-784, 2013.

47. Jutooru I, Chadalapaka G, Lei P and Safe S: Inhibition of NFkappaB and pancreatic cancer cell and tumor growth by curcumin is dependent on specificity protein down-regulation. J Biol Chem 285: 25332-25344, 2010.

48. Jutooru I, Chadalapaka G, Abdelrahim M, Basha MR, Samudio I, Konopleva M, Andreeff M and Safe S: Methyl 2-cyano-3,12 -dioxooleana-1,9-dien-28-oate decreases specificity protein transcription factors and inhibits pancreatic tumor growth: Role of microRNA-27a. Mol Pharmacol 78: 226-236, 2010.

49. Yang LJ, Chen Y, Ma Q, Fang J, He J, Cheng YQ and Wu QL: Effect of betulinic acid on the regulation of Hiwi and cyclin B1 in human gastric adenocarcinoma AGS cells. Acta Pharmacol Sin 31: 66-72, 2010.

50. Yuan P, Wang L, Wei D, Zhang J, Jia Z, Li Q, Le X, Wang H, Yao $\mathrm{J}$ and Xie K: Therapeutic inhibition of Sp1 expression in growing tumors by mithramycin a correlates directly with potent antiangiogenic effects on human pancreatic cancer. Cancer 110: 2682-2690, 2007.

51. Dvorak HF: Vascular permeability factor/vascular endothelial growth factor: A critical cytokine in tumor angiogenesis and a potential target for diagnosis and therapy. J Clin Oncol 20: 4368-4380, 2002

52. Dittmer TA and Misteli T: The lamin protein family. Genome Biol 12: 222, 2011

53. Broers JL, Ramaekers FC, Bonne G, Yaou RB and Hutchison CJ Nuclear lamins: Laminopathies and their role in premature ageing. Physiol Rev 86: 967-1008, 2006.

54. Broers JL, Raymond Y, Rot MK, Kuijpers H, Wagenaar SS and Ramaekers FC: Nuclear A-type lamins are differentially expressed in human lung cancer subtypes. Am J Pathol 143: 211-220, 1993.

55. Moss SF, Krivosheyev V, de Souza A, Chin K, Gaetz HP, Chaudhary N, Worman HJ and Holt PR: Decreased and aberrant nuclear lamin expression in gastrointestinal tract neoplasms. Gut 45: 723-729, 1999.

56. Coradeghini R, Barboro P, Rubagotti A, Boccardo F, Parodi S, Carmignani G, D'Arrigo C, Patrone E and Balbi C: Differential expression of nuclear lamins in normal and cancerous prostate tissues. Oncol Rep 15: 609-613, 2006.

57. Lim SO, Park SJ, Kim W, Park SG, Kim HJ, Kim YI, Sohn TS Noh JH and Jung G: Proteome analysis of hepatocellular carcinoma. Biochem Biophys Res Commun 291: 1031-1037, 2002.

58. Maeno H, Sugimoto K and Nakajima N: Genomic structure of the mouse gene (Lmnb1) encoding nuclear lamin B1. Genomics 30: 342-346, 1995 .

59. Lin F and Worman HJ: Expression of nuclear lamins in human tissues and cancer cell lines and transcription from the promoters of the lamin A/C and B1 genes. Exp Cell Res 236: 378-384, 1997.

60. Li L, Du Y, Kong X, Li Z, Jia Z, Cui J, Gao J, Wang G and Xie K: Lamin B1 is a novel therapeutic target of betulinic acid in pancreatic cancer. Clin Cancer Res 19: 4651-4661, 2013

61. Sun S, Xu MZ, Poon RT, Day PJ and Luk JM: Circulating Lamin B1 (LMNB1) biomarker detects early stages of liver cancer in patients. J Proteome Res 9: 70-78, 2010.

62. Karna E, Szoka L and Palka JA: Betulinic acid inhibits the expression of hypoxia-inducible factor 1alpha and vascular endothelial growth factor in human endometrial adenocarcinoma cells. Mol Cell Biochem 340: 15-20, 2010.

63. Gleadle JM and Ratcliffe PJ: Induction of hypoxia-inducible factor-1, erythropoietin, vascular endothelial growth factor and glucose transporter-1 by hypoxia: Evidence against a regulatory role for Src kinase. Blood 89: 503-509, 1997.

64. Van Waes C: Nuclear factor-kappaB in development, prevention and therapy of cancer. Clin Cancer Res 13: 1076-1082, 2007.

65. Patel HM, Rane R, Thapliyal N, Palkar M, Shaikh M and Karpoormath R: Epidermal growth factor receptor (EGFR) tyrosine kinase inhibitors from the natural origin: A recent perspective. Anticancer Agents Med Chem 15: 988-1011, 2015.

66. Nikiforov YE: RET/PTC rearrangement in thyroid tumors. Endocr Pathol 13: 3-16, 2002

67. Nikiforov YE and Nikiforova MN: Molecular genetics and diagnosis of thyroid cancer. Nat Rev Endocrinol 7: 569-580, 2011

68. Wada S and Tanaka R: Betulinic acid and its derivatives, potent DNA topoisomerase II in"hibitors, from the bark of Bischofia javanica. Chem Biodivers 2: 689-694, 2005. 
69. Ganguly A, Das B, Roy A, Sen N, Dasgupta SB, Mukhopadhayay S and Majumder HK: Betulinic acid, a catalytic inhibitor of topoisomerase I, inhibits reactive oxygen species-mediated apoptotic topoisomerase I-DNA cleavable complex formation in prostate cancer cells but does not affect the process of cell death. Cancer Res 67: 11848-11858, 2007.

70. Dillon LW, Pierce LC, Lehman CE, Nikiforov YE and Wang YH: DNA topoisomerases participate in fragility of the oncogene RET. PLoS One 8: e75741, 2013.

71. Kommera H, Kaluderovic GN, Kalbitz J and Paschke R: Synthesis and anticancer activity of novel betulinic acid and betulin derivatives. Arch Pharm (Weinheim) 343: 449-457, 2010.

72. Bache M, Bernhardt S, Passin S, Wichmann H, Hein A Zschornak M, Kappler M, Taubert H, Paschke R and Vordermark D: Betulinic acid derivatives NVX-207 and B10 for treatment of glioblastoma-an in vitro study of cytotoxicity and radiosensitization. Int J Mol Sci 15: 19777-19790, 2014.

73. Engelman JA: Targeting PI3K signalling in cancer: Opportunities, challenges and limitations. Nat Rev Cancer 9: 550-562, 2009.

74. Shaw RJ and Cantley LC: Ras, PI (3)K and mTOR signalling controls tumour cell growth. Nature 441: 424-430, 2006.

75. Madge LA, Li JH, Choi J and Pober JS: Inhibition of phosphatidylinositol 3-kinase sensitizes vascular endothelial cells to cytokine-initiated cathepsin-dependent apoptosis. J Biol Chem 278: 21295-21306, 2003.

76. Gonzalez P, Mader I, Tchoghandjian A, Enzenmuller S, Cristofanon S, Basit F, Debatin KM and Fulda S: Impairment of lysosomal integrity by B10, a glycosylated derivative of betulinic acid, leads to lysosomal cell death and converts autophagy into a detrimental process. Cell Death Differ 19: 1337-1346, 2012.
77. Pandey MK, Sung B and Aggarwal BB: Betulinic acid suppresses STAT3 activation pathway through induction of protein tyrosine phosphatase SHP-1 in human multiple myeloma cells. Int J Cancer 127: 282-292, 2010.

78. Yang LJ, Chen Y, He J, Yi S, Wen L, Zhao J, Zhang BP and Cui GH: Betulinic acid inhibits autophagic flux and induces apoptosis in human multiple myeloma cells in vitro. Acta Pharmacol Sin 33: 1542-1548, 2012.

79. Cheng YQ, Chen Y, Wu QL, Fang J and Yang LJ: Effect of betulinic acid on inducing apoptosis of human multiple myeloma cell line RPMI-8226. Zhongguo Shi Yan Xue Ye Xue Za Zhi 17: 1224-1229, 2009 (In Chinese).

80. Ehrhardt H, Fulda S, Fuhrer M, Debatin KM and Jeremias I: Betulinic acid-induced apoptosis in leukemia cells. Leukemia 18 1406-1412, 2004

81. Kumar D, Mallick S, Vedasiromoni JR and Pal BC: Anti-leukemic activity of Dillenia indica L. fruit extract and quantification of betulinic acid by HPLC. Phytomedicine 17: 431-435, 2010.

82. Wu Q, He J, Fang J and Hong M: Antitumor effect of betulinic acid on human acute leukemia K562 cells in vitro. J Huazhong Univ Technolog Med Sci 30: 453-457, 2010.

83. Chen Z, Wu Q, Chen Y and He J: Effects of betulinic acid on proliferation and apoptosis in Jurkat cells and its in vitro mechanism. J Huazhong Univ Sci Technolog Med Sci 28: 634-638, 2008

84. Chen Z, Wu QL, Chen Y and He J: Effect of betulinic acid on proliferation, apoptosis, and cell cycle of human lymphoma cell line Raji. Zhong Cao Yao Bian Ji Bu 4: 556-559, 2008. 